Article

\title{
Antimicrobial Effect of Plasma-Activated Tap Water on Staphylococcus aureus, Escherichia coli, and Candida albicans
}

\author{
William Chiappim $^{1, *(\mathbb{D}}$, Aline da Graça Sampaio ${ }^{2} \mathbb{D}$, Felipe Miranda ${ }^{1} \mathbb{D}$, Mariana Fraga $^{3, * \mathbb{D}}$, \\ Gilberto Petraconi ${ }^{1}(\mathbb{D})$, Argemiro da Silva Sobrinho ${ }^{1} \mathbb{D}$, Konstantin Kostov ${ }^{4} \mathbb{D}$, Cristiane Koga-Ito ${ }^{2,5} \mathbb{D}^{\mathbb{D}}$ \\ and Rodrigo Pessoa ${ }^{1, *}$ (D)
}

check for updates

Citation: Chiappim, W.; Sampaio, A.d.G.; Miranda, F.; Fraga, M.;

Petraconi, G.; da Silva Sobrinho, A.; Kostov, K.; Koga-Ito, C.; Pessoa, R. Antimicrobial Effect of

Plasma-Activated Tap Water on Staphylococcus aureus, Escherichia coli, and Candida albicans. Water 2021, 13, 1480. https://doi.org/10.3390/ w13111480

Academic Editor: Hodon Ryu

Received: 19 April 2021

Accepted: 22 May 2021

Published: 25 May 2021

Publisher's Note: MDPI stays neutral with regard to jurisdictional claims in published maps and institutional affiliations.

Copyright: (c) 2021 by the authors. Licensee MDPI, Basel, Switzerland. This article is an open access article distributed under the terms and conditions of the Creative Commons Attribution (CC BY) license (https:/ / creativecommons.org/licenses/by/ $4.0 /)$.
1 Laboratório de Plasmas e Processos, Instituto Tecnológico de Aeronáutica, Praça Marechal Eduardo Gomes 50, São José dos Campos 12228-900, Brazil; mirannda.fs@gmail.com (F.M.); petrafilho@gmail.com (G.P.); argemiro@ita.br (A.d.S.S.)

2 Oral Biopathology Graduate Program, São José dos Campos Institute of Science \& Technology, São Paulo State University, UNESP, São Paulo 12245-000, Brazil; aline.sampaio@unesp.br (A.d.G.S.); cristiane.koga-ito@unesp.br (C.K.-I.)

3 Instituto de Ciência e Tecnologia, Universidade Federal de São Paulo, Rua Talim 330, São José dos Campos 12231-280, Brazil

4 Faculty of Engineering (FEG)—São Paulo State University (UNESP), Guaratinguetá (SP) 12516-410, Brazil; konstantin.kostov@unesp.br

5 Department of Environment Engineering, São José dos Campos Institute of Science \& Technology, São Paulo State University, UNESP, São Paulo 12247-016, Brazil

* Correspondence: chiappimjr@yahoo.com.br (W.C.); mafraga@ieee.org (M.F.); rspessoa@ita.br (R.P.); Tel.: +55-12-3947-5785 (R.P.)

\begin{abstract}
In this study, the potential antimicrobial activity of plasma-activated tap water (PAW) was evaluated against Staphylococcus aureus, Escherichia coli, and Candida albicans. For this, PAW was prepared in a gliding arc plasma system using two treatment conditions: stagnant water and water stirring by a magnetic stirrer, called moving water. Subsequently, their oxidation-reduction potential (ORP), $\mathrm{pH}$, electrical conductivity $(\sigma)$, and total dissolved solids (TDS) were monitored in different areas of the sample divided according to the depth of the beaker. It was observed that PAW obtained in dynamic conditions showed a more uniform acidity among the evaluated areas with pH 3.53 and ORP of $215 \mathrm{mV}$. Finally, standardized suspensions of Staphylococcus aureus (ATCC 6538), Escherichia coli (ATCC 10799), and Candida albicans (SC 5314) were treated with PAW, and the reduction of viable cells determined the antimicrobial effect. Our results indicate that the tap water, activated by plasma treatment using gliding arc, is an excellent inactivation agent in the case of Staphylococcus aureus and Escherichia coli. On the other hand, no significant antimicrobial activity was achieved for Candida albicans.
\end{abstract}

Keywords: plasma activated water; tap water; atmospheric plasma; gliding arc discharge; Staphylococcus aureus; Escherichia coli; Candida albicans

\section{Introduction}

In recent years, plasma-activated water (PAW) has gained prominence due to its application in medicine [1-3], mainly due to the effects of inactivation in microbial species caused basically by the stimulation of high biochemical and biological activities that alter the properties of water due to its exposure to plasma [4-8]. This plasma water activation technique is inexpensive and environmentally friendly since it is free of chemicals [9]. For this type of application, atmospheric non-thermal plasmas (ANTP) are used, namely, the dielectric barrier discharge (DBD) or the gliding arc plasma jet (GAPJ) [10-17]. The plasma used as a water activating agent can be applied directly submerged in the liquid or applied to millimeters of the liquid's surface [18-24]. 
According to Zhou et al. [8], the plasma activates a mixture of reactive oxygen and nitrogen species (RONS) in water that is highly effective in the long term against resistant fungi, bacteria, and viruses. Therefore, RONS are primarily responsible for microbial inactivation, making PAW a potential candidate for application in clinical practice. The RONS generated in the exposure of water to plasma can include types of species with long life (between years and tens of minutes); namely, ozone $\left(\mathrm{O}_{3}\right)$, hydrogen peroxide $\left(\mathrm{H}_{2} \mathrm{O}_{2}\right)$, nitrates $\left(\mathrm{NO}_{3}{ }^{-}\right)$, and nitrites $\left(\mathrm{NO}_{2}{ }^{-}\right)$. Also, short-lived species (between seconds and nanoseconds) are generated, namely, peroxynitrite $\left(\mathrm{ONOO}^{-}\right)$, peroxynitrite $\left(\mathrm{OONO}_{2}{ }^{-}\right)$, superoxide $\left(\mathrm{O}_{2}{ }^{-}\right)$, nitric oxide $(\mathrm{NO} \bullet)$ and hydroxyl radicals $(\bullet \mathrm{OH})[8,13]$. Despite the good antimicrobial effect of PAW, it is essential to note that these reactive species can be dangerous to human health, and their activity in eukaryotic cells must be considered before any application. Recently, Han et al. [25] applied cold plasma directly to edible films to investigate subacute oral toxicity and demonstrated low toxicity without generating harmful by-products to human health. Borges et al. [26] showed that the direct use of a cold plasma jet on epithelial cells has low toxicity. Finally, Ibis and Ercan [27] evaluated the in-vitro toxicity of distilled water activated by plasma and, later, nebulized on healthy eukaryotic cells of the human tracheal epithelium where they demonstrated that there was no damage significant to eukaryotic cells. Therefore, it is evident that the application of plasma directly to the human cell, the most aggressive treatment method, causes low toxicity. On the other hand, recent studies have shown that there is no toxicity of PAW on healthy human eukaryotic cells.

Thinking about the construction of a bench device for water activation/treatment, which can be used in gynecological, dental, and medical clinics, it is more advantageous to use plasma applied to millimeters from the surface, which facilitates the architecture of building a device, without lose the effectiveness of inactivation of microbial species [8-17]. However, despite PAW's tremendous technological appeal, mainly due to its potent antimicrobial effects and wide application in clinical practice, some technical challenges need to be overcome. As an example, increasing the concentration of RONS produced.

As reported in the literature, the amount of RONS generated per unit volume of activated water is generally low, requiring a long time of exposure to plasma (several minutes or hours) to reach a sufficient amount of activated water [28-32]. Besides the limited volume of activated water, other factors inhibit the fabrication of portable equipment for clinical use. For example, the use of pure gases, such as oxygen, argon, and/or helium, in ANTP reactors [2,30-34] can be expensive, demanding high voltages to maintain the electrical discharge, in addition to having low efficiency in the production of RONS in high volumes. Another point that contributes to the increase in the costs of the process is the need for deionized or distilled water to control and standardize the water. To overcome these challenges, a versatile and low-cost PAW process is required. In this sense, air plasma, i.e., an electrical discharge that generates high-density plasma in the air [7,29,35-37], is an attractive source of low-cost and high-efficiency RONS. In this context, the forward vortex flow reactor (FVFR) emerges as a gliding arc (G arc) source that potentially has all requirements mentioned above $[38,39]$. Another fundamental point is the exchange of deionized or distilled water for tap water. This exchange is essential to reduce PAW's manufacturing costs, as these water purification processes require expensive equipment. Although tap water has different properties in each country, state, city, and even between neighborhoods, it is still a cheap and easily accessible alternative around the world. Even without a universal standardization of its properties and characteristics, tap water can be activated by plasma and used in medicine, agriculture, etc. In fact, this is done after a study of toxicity in living beings. Recently, PAW has become a frequently employed antimicrobial agent [24]. The processes that involve it can be divided into two types: the direct-PAW mode and the indirect-PAW mode. In the first, microorganisms present in the water are inactivated during the plasma treatment of the liquid. In the second case, the water previously treated by plasma is used to induce antibacterial/antifungal activity immediately after its generation or after some time. An exciting feature is that the 
PAW when adequately stored, can retain its antibacterial/antifungal properties for several days [40-42]. This long-term antimicrobial efficacy [42,43] can help to inactivate various microbiological species in regions far from the source of water activation, thus expanding PAW applications in areas far from large economic centers.

This experimental study is outlined as follows: first, the experimental setup is introduced based on the plasma jet generated in an FVFR-G arc reactor using compressed air placed a few millimeters from the surface of the tap water. The PAW produced by this device has been stored for later use. Two different modes of water treatment were tested: in the first case with stagnant water and in the second case with moving water with the aid of a magnetic stirrer. After plasma processing, the antimicrobial properties of the treated water were evaluated against Staphylococcus aureus (ATCC 6538), Escherichia coli (ATCC 10799), and Candida albicans (SC 5314). Finally, the impact of individual plasma parameters on tap water properties were discussed and their influence on PAW antimicrobial properties were assessed.

\section{Materials and Methods}

\subsection{Experimental Configuration for Obtaining PAW}

PAW was prepared by a gliding arc plasma system schematically shown in Figure 1. The experimental setup comprises a plasma reactor, a high-voltage power supply, an oscilloscope, an optical emission spectrometer and, an infrared camera. The gliding arc plasma was generated in a forward vortex flow reactor (FVFR) type [39], and the outer region is composed of plasma plume and post-discharge regions $[39,40]$. The gas used in this study was air generated by an air compressor (Schulz CSD 9/50, Joinville, SC, Brazil) with a flow of $5 \mathrm{~L} \mathrm{~min}{ }^{-1}$. This air flow was chosen due to the formation of a continuous gliding arc discharge with the lowest possible flow, as demonstrated by Doria et al. [39]. The system was powered by a high-voltage transformer (Linsa, Indústria Eletro Mecânica Linsa LTDA, São Paulo, SP, Brazil) operating at $7.5 \mathrm{kV}$ and $60 \mathrm{~Hz}$. A high-voltage resistance (approx. $1 \mathrm{k} \Omega$ ) was used to protect the transformer in case of an electric arc. A Variac transformer (VARIAC, Cleveland, OH, USA) was used to adjust the high voltage of the plasma reactor.

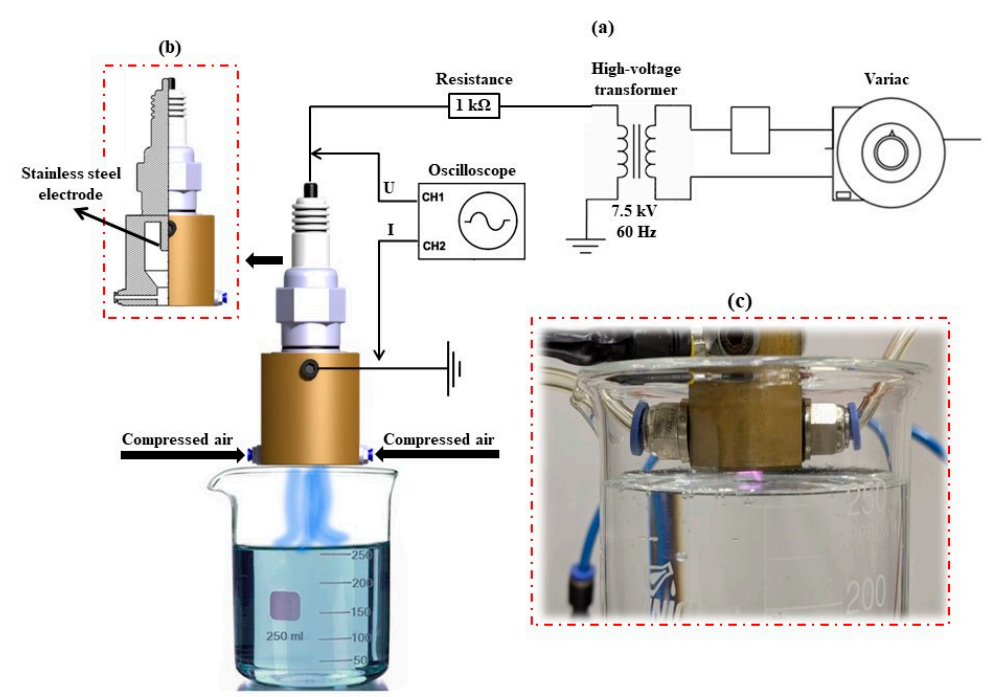

Figure 1. (a) Experimental setup, (b) reactor, and (c) photograph of the FVFR G-arc reactor for treatment of tap water.

A $250 \mathrm{~mL}$ beaker containing tap water collected at the Laboratório de Plasmas e Processos (LPP-23 $12^{\prime} 31.2^{\prime \prime} \mathrm{S} 45^{\circ} 52^{\prime} 40.9^{\prime \prime} \mathrm{W}$ ) ( $\mathrm{pH}$ of 6.53 and with a soft hardness of $2.0 \mathrm{mg} / \mathrm{L} \mathrm{CaCO}_{3}$ ) (dataset obtained in São José dos Campos—São Paulo—Brazil according to the National Institute of Metrology, Standardization and Industrial Quality, Inmetro [44]) was placed on a magnetic stirrer (Kasvi CK FG, Kasvi, São José dos Pinhais, PR, Brazil) 
and the nozzle of the gliding arc reactor was positioned $5 \mathrm{~mm}$ from the water surface. The water treatment time was $30 \mathrm{~min}$.

To obtain the electrical signals from the gliding arc discharge, a high voltage probe (Tektronix P6015A, Tektronix, Beaverton, OR, USA) and a self-adjusting current probe (Agilent N2869B, Agilent, Santa Clara, CA, USA) were used. All electrical signals were recorded on a digital oscilloscope (Keysight DSOX1202A, Keysight, Santa Rosa, CA, USA), and the current signal was inferred directly from the grounded electrode. A photo of the discharge configuration (Figure 1c) was taken with a smartphone (Google Pixel 3XL, Google, Mountain View, CA, USA).

Doria et al. [39] reported an increase in the error measured for the discharge power due to the fact that some charged particles escape from the plasma plume. Schmidt et al. [24], related the same problem using distinct plasma reactors. Based on this problem, to calculated the electrical power dissipated into the plasma $\left(P_{\text {dissip }}\right)$, Doria et al. [39] suggested using the following equation:

$$
P_{\text {dissip }}(W)=\frac{1}{T_{2}-T_{1}} \int_{T_{1}}^{T_{2}} V(t) I(t) d t
$$

where $V(t)$ is voltage, $I(t)$ is the electric current and $T_{2}-T_{1}$ is the time interval.

Figure 2a shows the typical waveforms for discharge voltage and current recorded by oscilloscope using a fixed Variac control position. As can be seen, the peak-to-peak voltage is $2694 \mathrm{~V}$ for air flow of $5.0 \mathrm{~L} \mathrm{~min}^{-1}$.

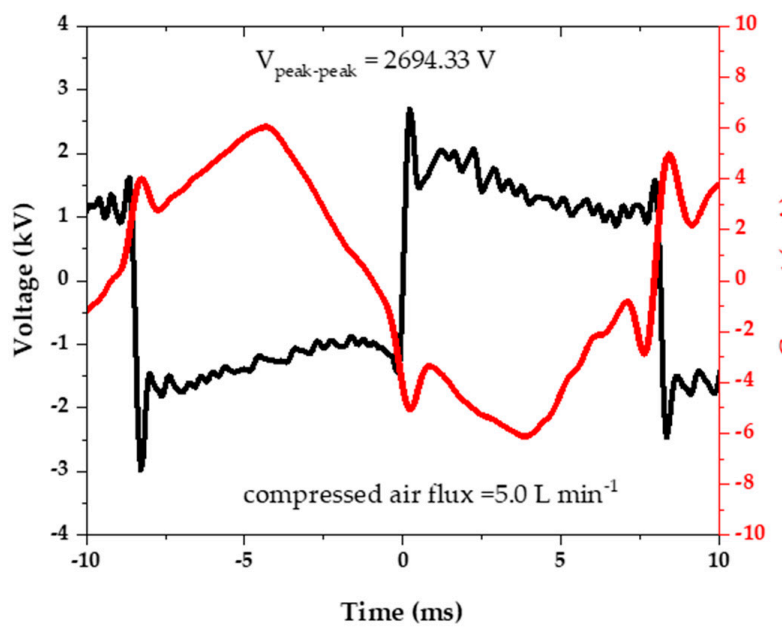

(a)

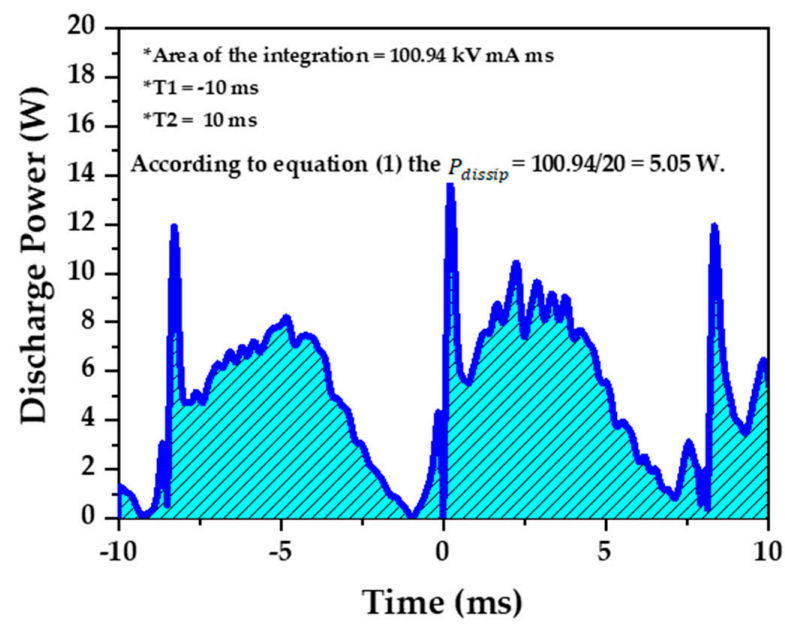

(b)

Figure 2. (a) Discharge voltage and current waveforms of G-arc operating with air flow of $5 \mathrm{~L} \mathrm{~min}^{-1}$ and (b) waveform of $\mathrm{G}$-arc discharge power used to calculate the mean power through Equation (1).

Figure $2 \mathrm{~b}$ illustrates the instantaneous discharge power waveform as a function of time. It is worth highlighting that the integral of the curve over a time interval $\left(T_{2}-T_{1}\right)$ of $20 \mathrm{~ms}$ allows to obtain a mean power in the discharge of $5.1 \mathrm{~W}$. As a consequence, the consumption of $10 \mathrm{Wh}$ for the production of $1 \mathrm{~L} \mathrm{PAW}$ is equivalents to a nowadays expense of below $0.01 \$$ or $0.01 €$ per liter for electricity and water. Therefore, the choice of compressed air gas is justified.

Optical emission spectroscopy (OES) was used to characterize the main plasma species in UV-visible range of 200-500 nm. For this, an optical emission spectrometer (Ocean Optics USB4000, Ocean Insights, Rockster, NY, USA) with a resolution of $1.5 \mathrm{~nm}$ was used. The OceanView software (OceanView Software, Ocean Insights, Rockster, NY, USA) was used to acquire the optical spectrum. As shown in Figure 3, the optical emission spectrum of the air plasma contains $\mathrm{NH}, \mathrm{N}_{2}$, and $\mathrm{OH}$ species, which come from atmospheric air [39]. 


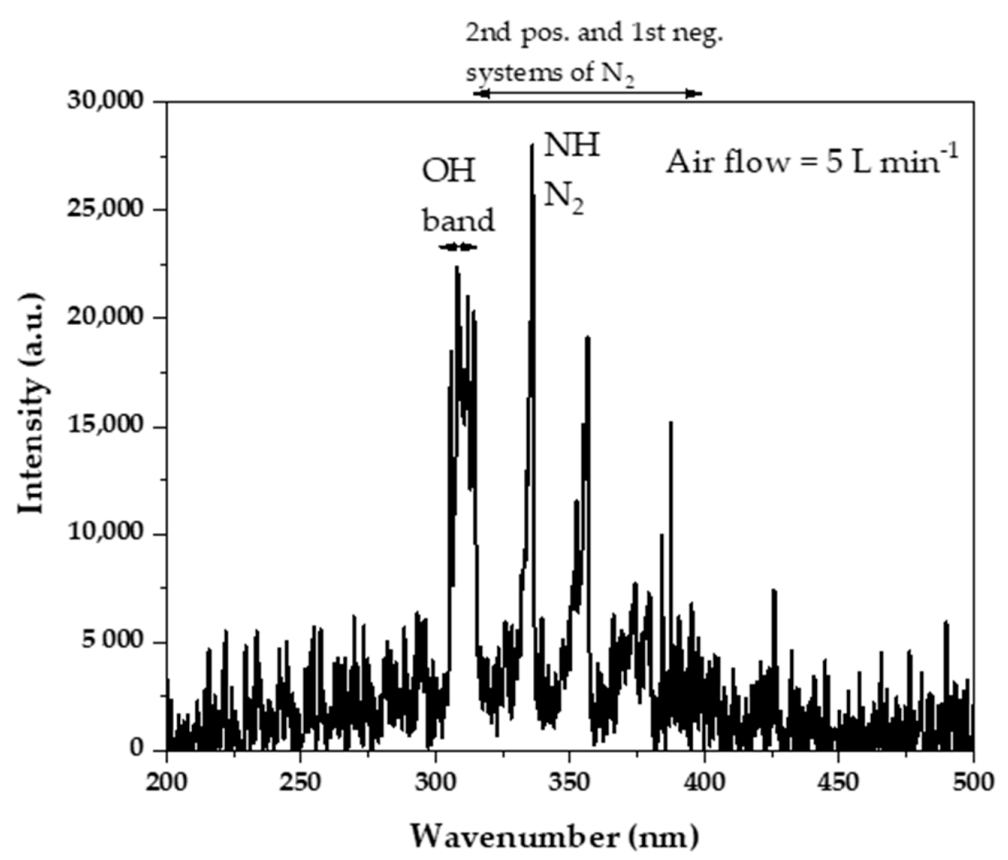

Figure 3. OES spectrum of gliding arc plasma jet operating at air flow of $5 \mathrm{~L} \mathrm{~min}^{-1}$ and discharge power of $5.1 \mathrm{~W}$.

It is worth mentioning that both the electrical and the optical emission parameters presented aimed at detail the plasma used to treat the tap water. As the work is focused on the changes generated in tap water and its antimicrobial effect, we find it more convenient to present these data in this section instead of showing them in results and discussions.

Finally, thermal images of the water during plasma treatment were taken using an IR camera (model TiS 10, Fluke, Everett, WA, USA).

\subsection{Water Physicochemical Properties Measurements}

The $\mathrm{pH}$ value, the oxidation-reduction potential (ORP), the electrical conductivity $(\sigma)$, the total dissolved solids (TDS), as well as the water temperature were measured with a multiparameter (Mult-007, IonLab, Araucária, PR, Brazil), right after the plasma activation process. For the evaluation of the physical-chemical parameters, the experiment was designed as follows. Tap water was placed in a $250 \mathrm{~mL}$ beaker on a magnetic stirrer, and two forms of treatment were performed. In the first case, the tap water was exposed to the plasma with the agitator turned off, and in the second case, the agitator was kept on at $200 \mathrm{rpm}$. Tap water before plasma activation was used as a control sample. Firstly, the effect of treatment time in stagnant and stirring water modes was studied with the multiparameter water sensors (Multisensor, IonLab, Araucária, PR, Brazil) positioned at the bottom of the beaker. For this step, tap water samples $(250 \mathrm{~mL})$ were treated between 5 to $30 \mathrm{~min}$ with water samples divided into six sets corresponding to different plasma exposure times $(5,10,15,20,25$ and $30 \mathrm{~min})$ for each mode. It is essential to mention that to maintain the same activation kinetics of PAW, tap water $(250 \mathrm{~mL})$ was changed for each time of exposure to plasma $(5,10,15,20,25$ and $30 \mathrm{~min})$. This methodology was repeated for sets of samples every $5 \mathrm{~min}$ for both forms of water treatment. It is worth mentioning that, for each sample, the measurements were repeated five times.

The second part of the study aimed to evaluate the variation of the PAW physicochemical parameters along with the depth of the beaker right after the plasma treatment for the stagnant and agitated water modes. Figure 4 illustrates the sensors' positions at different points in the beaker used to measure the physicochemical parameters of the PAW. 


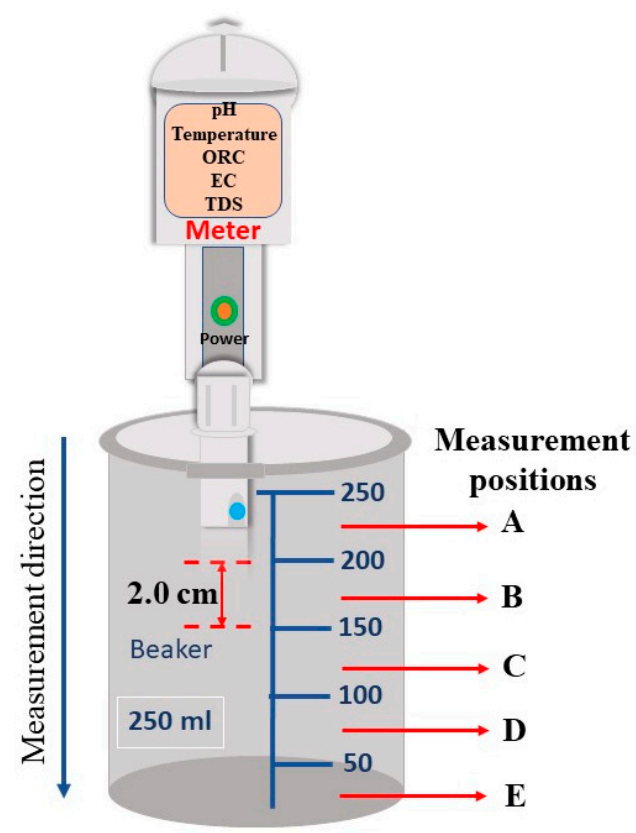

Figure 4. Water characterization points before and after plasma treatment using the multi-parameter meter as a function of depth.

A gradient of the RONS content along with the depth of the beaker can be expected with a higher concentration near the arc nozzle $G$ and a lower concentration at the bottom of the beaker. Measurements were performed in five vertically aligned positions defined below: position A (between 250 and $200 \mathrm{~mL}$ ), position B (between 200 and $150 \mathrm{~mL}$ ), position $\mathrm{C}$ (between 150 and $100 \mathrm{~mL}$ ), position $\mathrm{D}$ (between 100 and $50 \mathrm{~mL}$ ) and position $\mathrm{E}$ (between 50 and $0 \mathrm{~mL}$ ). Also, an investigation of the evolution of the PAW physicochemical parameters was carried out. The methodology used in both water treatment modes consisted of measuring water characteristics at three different times after treatment: the first data acquisition was 5 min after treatment, the second measurement $2 \mathrm{~h}$ after treatment, and the third measurement, which occurred $24 \mathrm{~h}$ after treatment. It is worth mentioning that the PAW was kept at room temperature $\left(25^{\circ} \mathrm{C}\right)$ in the beaker, and the measurements were repeated five times.

\subsection{Microbiological Assays}

\subsubsection{Strains and Inocula Preparation}

Reference strains of a Gram-positive bacterium Staphylococcus aureus (ATCC 6538), Gram-negative bacterium Escherichia coli (ATCC 10799), and the fungus Candida albicans (SC 5314) were included in this study. The strains were plated on tryptic soy agar (TSA), Broth Heart Infusion (BHI), and Sabouraud dextrose, respectively. Plates were incubated at $37^{\circ} \mathrm{C}$ for $24 \mathrm{~h}$, under aerobiosis. Then, standardized suspensions containing $10^{6}$ cells $/ \mathrm{mL}$ of each microbial species were prepared in sterile saline solution $(\mathrm{NaCl} 0.9 \%)$ with the aid of a spectrophotometer (AJX-1600, Micronal, São Paulo, SP, Brazil), according to the following parameters: wavelength $(\lambda)$ of $490 \mathrm{~nm}$ and optical density (O.D.) of 0.374 for S. aureus, $\lambda=600 \mathrm{~nm}$ and O.D. $=0.050$ for E. coli, and $\lambda=530 \mathrm{~nm}$ and O.D. $=0.138$ for C. albicans.

\subsubsection{Antimicrobial Activity}

For the evaluation of antimicrobial activity, the groups tested were: (i) PAW (pH 3.5); (ii) Non-activated tap water (TW) (negative control, $\mathrm{pH}$ 6.5); and (iii) Sterile distilled water adjusted to $\mathrm{pH} 3.5$ (low $\mathrm{pH}$ control). The low $\mathrm{pH}$ control was included as a control to evaluate the possible effect of the low $\mathrm{pH}$ on the microorganisms. PAW was sterilized by filtration using a $0.22 \mu \mathrm{m}$ membrane (Biofil Syringe filter, Microlab Scientific Co., Mongkok, Kowloon, Hongkong), with the aid of a sterile syringe. An aliquot of $125 \mu \mathrm{L}$ of the 
microbial suspension was added to $875 \mu \mathrm{L}$ of PAW in microtubes, homogenized, and maintained for 10 and $30 \mathrm{~min}$. Afterward, serial dilutions of the suspension were obtained in sterile saline solution $(\mathrm{NaCl} 0.9 \%)$. An aliquot of $100 \mu \mathrm{L}$ were plated on tryptic soy agar (TSA) for S. aureus, Broth Heart Infusion (BHI) for E. coli, and Sabouraud dextrose for C. albicans, according to the method described by Miles et al. [45]. Plates were incubated at $37^{\circ} \mathrm{C}$ for $24 \mathrm{~h}$, under aerobiosis. After the incubation period, the number of colonies was counted, and the value of colony-forming units per milliliter was calculated (CFU / mL). The experiments were carried out in triplicate.

\subsubsection{Statistical Analysis}

Graphpad Prism v7.0 software (Graphpad Company, San Diego, CA, USA) was used to perform the statistical analysis and plot the graphs. Data was previously analyzed by the normality test. Results on antimicrobial effect were compared by One-way Analysis of variance (ANOVA) and Tukey's post hoc test for the S. aureus and C. albicans groups. As data obtained for E. coli was not normally distributed, they were compared by Kruskal-Wallis and Dunn's post hoc tests. The level of significance was set at $5 \%$.

\section{Results and Discussion}

\subsection{Physicochemical Measurements and Thermal Analysis of Water}

It is worth mentioning that the water collected from different taps in the same building did not present other properties or parameters. In this case, it was not necessary to use an error bar in physicochemical parameters. Even so, in buildings with older pipes or with the possibility of taps with little use, there is probably some variation in the water parameters, basically due to the fact that the water line is slightly older. In such cases, better attention will be required to the collected parameters.

\subsubsection{Effect of Treatment Time}

Figure 5 a show the $\mathrm{pH}$ and ORP measurements as a function of the treatment time for the conditions of stirrer turned off and stirrer turned on during the plasma-activated water. It is important to note that the measurements were performed at the bottom of the beaker.

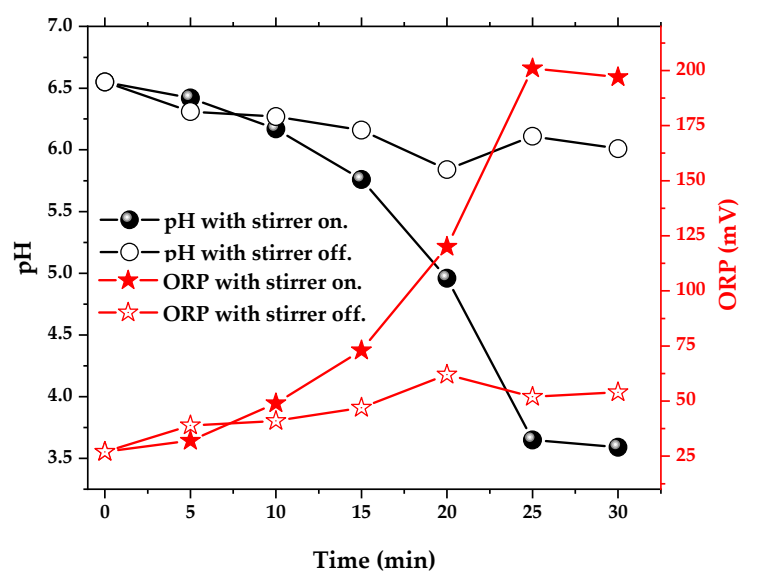

(a)

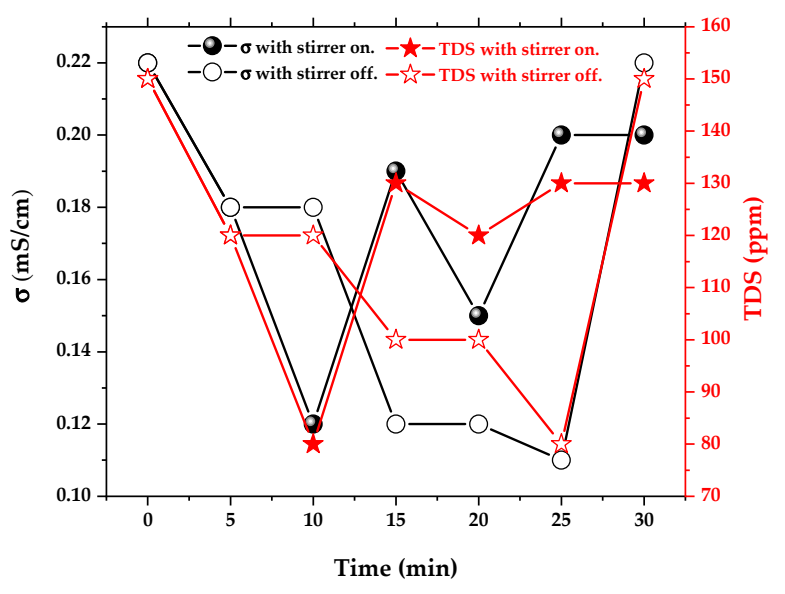

(b)

Figure 5. (a) $\mathrm{pH}$ and oxidation-reduction potential (ORP) of water as a function of plasma treatment time for conditions of stirrer on and off during the plasma activation. (b) electrical conductivity and total dissolved solids of water as a function of plasma treatment time for conditions of stirrer on and off during the plasma activation (error bar is not shown in the graphs ( $\mathrm{pH}$ error $( \pm 0.05)$; ORP error $( \pm 5 \mathrm{mV})$; $\sigma$ error $( \pm 5 \mu \mathrm{S} / \mathrm{cm})$; TDS error $( \pm 5))$.

It can be noted here a different behavior between the stagnant water and water stirring by a magnetic stirrer, both for $\mathrm{pH}$ and for ORP. When the plasma jet is placed a few millimeters from the water surface and treatment is started on $250 \mathrm{~mL}$ of stagnant 
water, there is a slow diffusion of RONS species through the water volume, making it difficult for these species to migrate to the bottom of the beaker, this translates into a slow reduction in $\mathrm{pH}(6.53 \pm 0.05$ to $6.00 \pm 0.05)$ and an increase in ORP $(26 \pm 5$ to $52 \pm 5 \mathrm{mV})$ at the beaker's bottom. This fact is not observed, however in the case where the water remained agitated throughout the treatment. In this case, there was a drastic decrease with subsequent saturation of the $\mathrm{pH}$ value after $25 \mathrm{~min}$ of treatment. For the ORP, there was an exponential increase in its value during the $25 \mathrm{~min}$ of treatment and subsequent saturation at $200 \pm 0.05 \mathrm{mV}$. These results demonstrate the importance of stirring large amounts of water during water treatment with a gliding arc plasma jet in non-contact mode. In a recent study, M. Schmidt et al. [24] used an Inductively-Limited Discharge to activate $500 \mathrm{~mL}$ of tap water and, after $30 \mathrm{~min}$, reached a $\mathrm{pH}=6$. F. Judeé et al. [12] used a DBD system for tap water treatment and a $\mathrm{pH}$ reduction from 7.5 to 6.5 was observed. Thus, the use of the gliding arc system with moving water proved to be a very efficient activation treatment for tap water.

Due to the lack of studies with tap water using air as a gas plasma source, as a comparison, studies that investigated the ORP of sterile distilled water (SDW) were used. According to Q. Xiang et al. [46,47], the ORP increased from 546 to $552 \mathrm{mV}$ after the G Arc treatment of $200 \mathrm{~mL}$ of SWD at discharge power of $750 \mathrm{~W}$ and a compressed air flux of $30 \mathrm{~L} \mathrm{~min}^{-1}$ for $30 \mathrm{~s}$ without stirring. Zhao et al. [48], using an atmospheric cold plasma jet (ACPJ), treated $30 \mathrm{~mL}$ of SWD for $5 \mathrm{~min}$ in static mode. They observed an increase in PAW's ORP value to 546.77, 558.57, and $565.40 \mathrm{mV}$ at 15,22 , and $30 \mathrm{kV}$, respectively, showing that the voltage had a significant impact on the oxidation-reduction potential. On the other hand, D. Cheng et al. [49], using an atmospheric-pressure plasma jet (APPJ), observed an ORP increase from 224.7 to $463.8 \mathrm{mV}$ in SWD after 20 min of plasma treatment and with a magnetic stirrer. These results corroborate our data (Figure 5a) and show the importance of stirring in the PAW process.

Figure $5 \mathrm{~b}$ show the $\sigma$ and TDS measurements as a function of the treatment time for the stirrer's conditions turned off, and stirrer turned on during the plasma-activated water. As demonstrated for $\mathrm{pH}$ and ORP measurements, it can be stated that a different behavior as a function of plasma treatment time occurs between the stagnant water and water stirring by a magnetic stirrer, both for $\sigma$ and TDS. Figure $5 \mathrm{~b}$ shows that during the first $25 \mathrm{~min}$ of activation, $\sigma$ decreases. For plasma activation time greater than $25 \mathrm{~min}$, the electrical conductivity increases and abruptly returns to the tap water value before the activation, i.e., $220 \pm 5 \mu \mathrm{S} / \mathrm{cm}$. In the case of stirrer on, during the first $10 \mathrm{~min}$ of activation, $\sigma$ decreases from $220 \pm 5$ to $115 \pm 5 \mu \mathrm{S} / \mathrm{cm}$. For plasma activation time higher than $10 \mathrm{~min}$, $\sigma$ increases more slowly to the value of $220 \pm 5 \mu \mathrm{S} / \mathrm{cm}$ in comparison with stagnant water experiment. F. Judeé et al. [12] used a DBD system for tap water treatment. They observed similar behavior with a decrease from 647.33 to $614 \mu \mathrm{S} / \mathrm{cm}$ in the first $5 \mathrm{~min}$. For 5 and 30 min of plasma exposure, they found that $\sigma$ increased linearly with activation time, in a range covering values from 614 to $731.33 \mu \mathrm{S} / \mathrm{cm}$. M. Schmidt et al. [24] found that after $30 \mathrm{~min}$ of tap water plasma treatment, they achieved an increase in $\sigma$ of less than $50 \mu \mathrm{S} / \mathrm{cm}$ (from $\sim 600$ to $650 \mu \mathrm{S} / \mathrm{cm}$ ). In the case of TDS measurements, the behavior was the same of $\sigma$ (as can be seen in Figure $5 b$ ) due to the direct relationship between dissolved solids in the liquid and conductivity.

\subsubsection{Effect of Water Dynamic Plasma Activation}

Table 1 shows the physicochemical parameters of the PAW along the depth of the beaker after plasma treatment for both modes. The $\mathrm{pH}, \mathrm{ORP}, \sigma$, TDS and temperature in both modes were measured after $5 \mathrm{~min}, 2 \mathrm{~h}$ and $24 \mathrm{~h}$ of plasma treatment. During all characterization, the PAW was kept at room temperature $\left(25^{\circ} \mathrm{C}\right)$ in the beaker. As shown in Table 1, the stagnant tap water activated by plasma has a reduced diffusion across the volume of water, making it difficult for these species to migrate to the bottom of the beaker. At $5 \mathrm{~min}$, a gradient of temperature of $43 \pm 1$ in position $\mathrm{A}$ to $37 \pm 1^{\circ} \mathrm{C}$ in position $\mathrm{E}$ was observed. This heating effect was expected due to the proximity of the plasma jet 
to the water surface. For this same analysis time, it was observed that in position A the $\mathrm{pH}=2.77 \pm 0.05$, but at the bottom of the beaker (position $\mathrm{E}$ ) the $\mathrm{pH}=6.05 \pm 0.05$, showing the difficulty of activation of the entire liquid volume when the water is kept static. In turn, the ORP at the top of the PAW (position A) has approximately 6 times higher value when compared to the ORP at the lowest position (position E). Both the $\sigma$ and TDS exhibit the same behavior as ORP.

Table 1. Measurements of the physicochemical parameters of the non-treated tap water and PAW in both modes realized at $5 \mathrm{~min}, 2 \mathrm{~h}$ and $24 \mathrm{~h}$ after the activation by plasma (according to the equipment manual, all measured parameters have an error of $\pm 2 \%$ ).

\begin{tabular}{|c|c|c|c|c|c|c|}
\hline $\begin{array}{c}\text { Time after } \\
\text { PAW }\end{array}$ & $\begin{array}{l}\text { Sensor } \\
\text { Position }\end{array}$ & $\begin{array}{c}\text { pH } \\
( \pm 0.05)\end{array}$ & $\begin{array}{l}\text { Temperature } \\
\left( \pm \mathbf{1}^{\circ} \mathrm{C}\right)\end{array}$ & $\begin{array}{c}\text { ORP } \\
( \pm 7 \mathrm{mV})\end{array}$ & $\begin{array}{c}\sigma \\
( \pm 5 \mu S / \mathrm{cm})\end{array}$ & $\begin{array}{c}\text { TDS } \\
( \pm 5 \text { ppm) }\end{array}$ \\
\hline \multicolumn{7}{|c|}{ Control sample } \\
\hline \multirow[t]{2}{*}{ - } & A to $E$ & 6.55 & 25 & 27 & 220 & 150 \\
\hline & \multicolumn{5}{|c|}{ PAW sample-Stagnant water } & \\
\hline \multirow{5}{*}{$5 \mathrm{~min}$} & A & 2.77 & 43 & 239 & 540 & 370 \\
\hline & B & 2.80 & 43 & 237 & 480 & 330 \\
\hline & $\mathrm{C}$ & 3.40 & 43 & 217 & 400 & 280 \\
\hline & D & 5.55 & 39 & 75 & 280 & 190 \\
\hline & $\mathrm{E}$ & 6.05 & 37 & 51 & 220 & 150 \\
\hline \multirow{5}{*}{$2 \mathrm{~h}$} & A & 3.33 & 25 & 212 & 240 & 160 \\
\hline & B & 3.98 & 25 & 167 & 230 & 152 \\
\hline & $\mathrm{C}$ & 3.96 & 25 & 165 & 220 & 150 \\
\hline & D & 3.95 & 25 & 165 & 220 & 150 \\
\hline & $\mathrm{E}$ & 3.96 & 25 & 165 & 220 & 150 \\
\hline \multirow{5}{*}{$24 \mathrm{~h}$} & A & 3.85 & 25 & 183 & 220 & 150 \\
\hline & B & 3.85 & 25 & 183 & 220 & 150 \\
\hline & $\mathrm{C}$ & 3.85 & 25 & 183 & 220 & 150 \\
\hline & $\mathrm{D}$ & 3.85 & 25 & 183 & 220 & 150 \\
\hline & $\mathrm{E}$ & 3.85 & 25 & 183 & 220 & 150 \\
\hline \multicolumn{7}{|c|}{ PAW sample-Stirred water } \\
\hline \multirow{5}{*}{$5 \mathrm{~min}$} & A & 3.21 & 34 & 221 & 210 & 80 \\
\hline & $\mathrm{B}$ & 3.33 & 33 & 212 & 210 & 90 \\
\hline & $\mathrm{C}$ & 3.32 & 33 & 211 & 220 & 150 \\
\hline & $\mathrm{D}$ & 3.31 & 32 & 211 & 220 & 150 \\
\hline & $\mathrm{E}$ & 3.48 & 32 & 199 & 220 & 150 \\
\hline \multirow{5}{*}{$2 \mathrm{~h}$} & A & 3.53 & 25 & 215 & 220 & 150 \\
\hline & B & 3.53 & 25 & 215 & 220 & 150 \\
\hline & $\mathrm{C}$ & 3.53 & 25 & 215 & 220 & 150 \\
\hline & D & 3.53 & 25 & 215 & 220 & 150 \\
\hline & $\mathrm{E}$ & 3.53 & 25 & 215 & 220 & 150 \\
\hline \multirow{5}{*}{$24 \mathrm{~h}$} & A & 3.53 & 25 & 215 & 220 & 150 \\
\hline & B & 3.53 & 25 & 215 & 220 & 150 \\
\hline & $\mathrm{C}$ & 3.53 & 25 & 215 & 220 & 150 \\
\hline & $\mathrm{D}$ & 3.53 & 25 & 215 & 220 & 150 \\
\hline & $\mathrm{E}$ & 3.53 & 25 & 215 & 220 & 150 \\
\hline
\end{tabular}

Two hours after the plasma treatment, all measured parameters exhibit much better homogeneity. However, only $24 \mathrm{~h}$ after the treatment in static mode, the PAW parameters reached stability with the same values for all measured positions in the beaker. While the water temperature, conductivity, and TDS returned to their initial values, the $\mathrm{pH}$ factor and ORP still maintain values that are different from those of untreated water.

On the other hand, only $5 \mathrm{~min}$ after plasma treatment, the water stirred presents a quasi-stability of the physicochemical parameters of the PAW. After $2 \mathrm{~h}$, the total homogeneity of all parameters of the PAW is achieved. Therefore, based on $\mathrm{pH}$ and ORP results, respectively, $3.53 \pm 5$ and $215 \pm 7 \mathrm{mV}$, the PAW treated for $30 \mathrm{~min}$ in the dynamic mode was chosen as the best option for the inactivation of microbiological species investigated in this work. 
According to the literature $[24,50,51]$, the continuous decrease in $\mathrm{pH}$ of the plasmaactivated nonbuffered solution (soft hardness of $2.0 \mathrm{mg} / \mathrm{L} \mathrm{CaCO}_{3}$ of our tap water) with increasing treatment time form new chemical species that be responsible for the decrease in the $\mathrm{pH}$ of water. However, as shown in Figure $5 \mathrm{a}$ the $\mathrm{pH}$ reaches a steady state after a certain activation period and remains constant. Another parameter that increased 10 times after the treatment was the ORP, which determines the ability of solutions to oxidize or reduce a substance. The ORP concerns the concentration of oxidizers and their strength or activity [50]. ORP is reported to be the principal responsible for destructing microbiological systems' membrane integrity with the fundamental function of affecting the cells' inner and outer membranes [52]. Among the RONS generated in PAW, hydrogen peroxide $\left(\mathrm{H}_{2} \mathrm{O}_{2}\right)$ is mainly responsible for the formation of ORP [53] and has a rapid potential for disinfection of liquids $[17,54,55]$.

\subsubsection{Thermal Analysis of tap Water during Plasma Treatment}

Figure 6 show the infrared thermal images of the beaker with water during the plasma treatment in stagnant and stirred modes, respectively. The thermal images of the beaker during the activation of the water by plasma were recorded in $0 \mathrm{~min} ; 1 \mathrm{~min} ; 5 \mathrm{~min} ; 10 \mathrm{~min}$; $15 \mathrm{~min} ; 20 \mathrm{~min}$; and $30 \mathrm{~min}$, respectively. For stagnant water, a slow temperature gradient can be seen through the color gradient. This behavior can be compared to the difficulty of reactive species from plasma, such as RONS, in migrating to the bottom of the beaker, a fact that is correlated to the slow reduction in $\mathrm{pH}$ over the volume of water (as shown in Figure 5a). However, this fact is not observed in the case where the water remained agitated throughout the treatment. In this case, a continuous temperature gradient occurs, where, in 20 min of treatment, a continuum of the color gradient was observed which shows a thermal balance of the PAW contained in the beaker. This result resonates with the saturation of $\mathrm{pH}$ and ORP presented in Figure $5 \mathrm{a}$ (stirred on). Therefore, the thermal analysis of water during the plasma activation process demonstrates the importance of the effect of agitating large volumes of water during its treatment, especially for the case of non-contact plasma jet treatment.

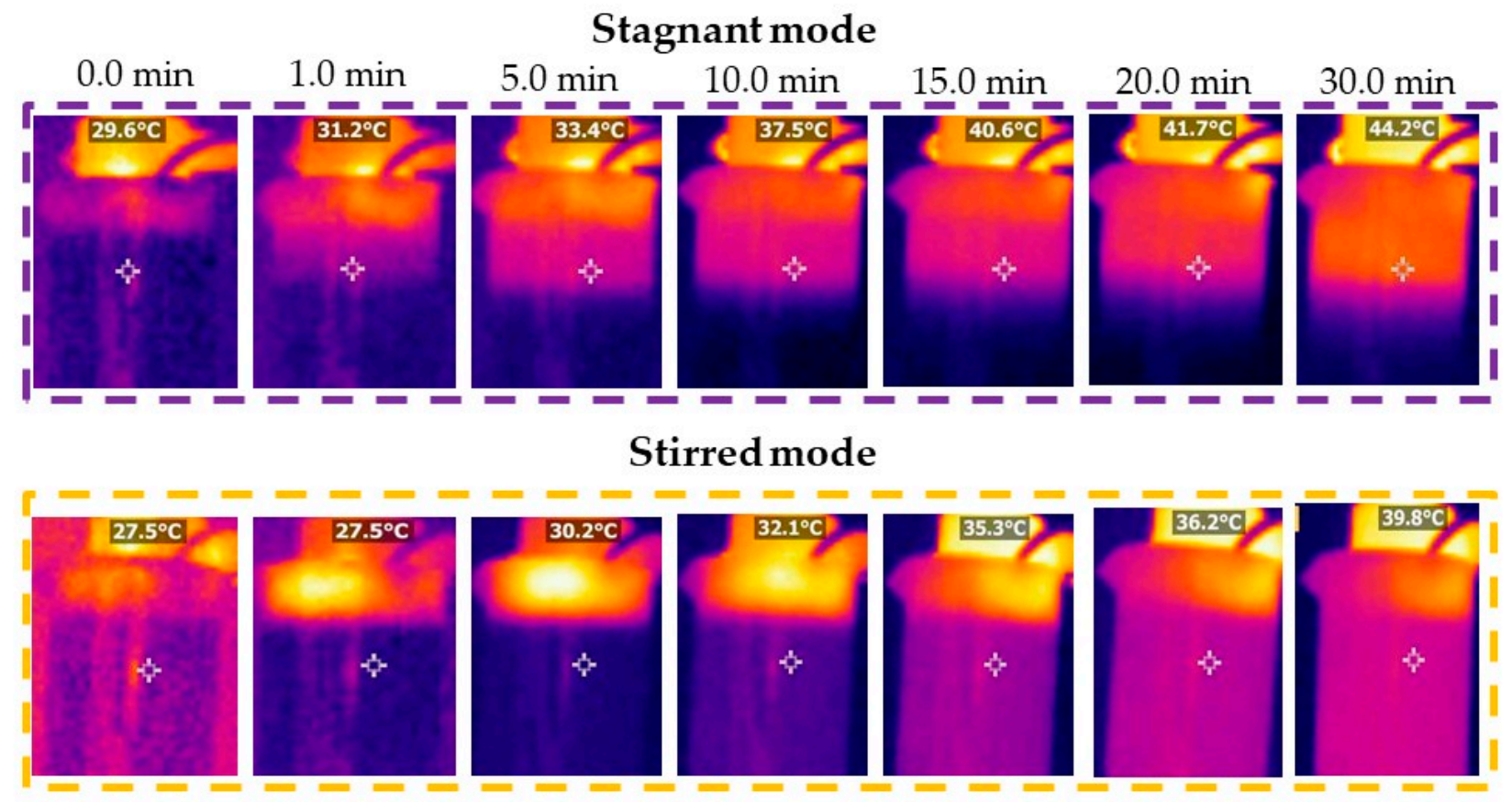

Figure 6. Thermal images of tap water during plasma treatment in stagnant and stirred mode: thermal image of the beaker during: $0 \mathrm{~min}$; $1 \mathrm{~min} ; 5 \mathrm{~min} ; 10 \mathrm{~min} ; 15 \mathrm{~min} ; 20 \mathrm{~min}$; and $30 \mathrm{~min}$ of plasma treatment. 


\subsection{Microbiological Analyses}

To screen PAW antimicrobial activity, three clinically relevant microbial species, were included in the study. Staphylococcus aureus and Escherichia coli were included, as they are related to infections acquired in hospital environments [55] and represent the main groups of bacteria (Gram-positive and Gram-negative, respectively). Candida albicans are a species of opportunistic fungus that can cause various human diseases, from superficial to widespread infections [56]. Therefore, the inclusion of several microbial species in antimicrobial screening studies is vital due to the different cellular structures and metabolism that considerably affect susceptibility.

Figure 7 shows the results obtained for the effect of PAW in S. aureus. As can be seen, a significant reduction in viable cells was detected after contact with PAW for $10 \mathrm{~min}$ and distilled water $\mathrm{pH} 3.5(p=0.0001)$ when compared to non-activated tap water $(p=0.0035)$.

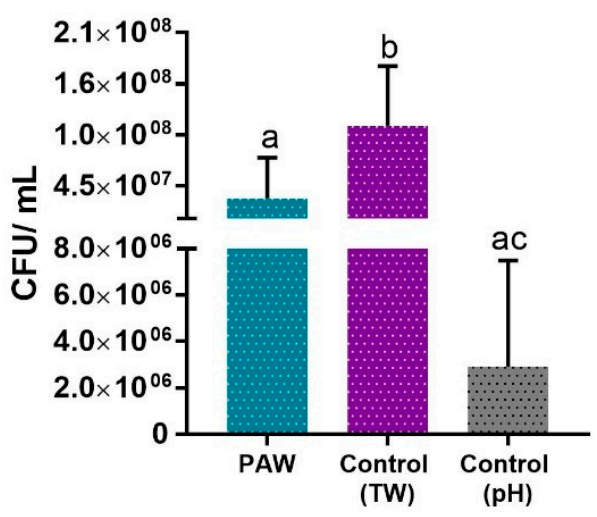

Time $10 \mathrm{~min}$

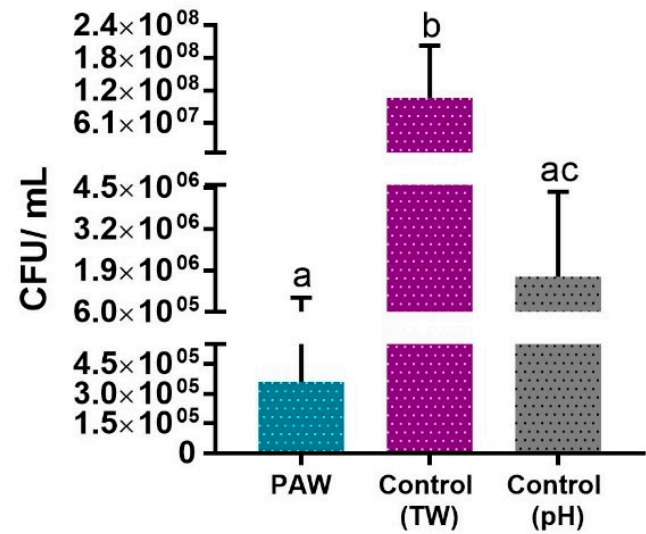

Time $30 \mathrm{~min}$

(a)

(b)

Figure 7. Mean and standard deviation of the number of Staphylococcus aureus viable cells (CFU/mL) after exposure to plasma-activated water (PAW) for 10 and $30 \mathrm{~min}$. TW: non-activated tap water (negative control); Control (pH): distilled water $\mathrm{pH}$ 3.5. Different superscript letters indicate significant differences among the groups. $(p<0.05)$ based on ANOVA statistical test followed by Tukey's post hoc test.

Exposure to PAW for $30 \mathrm{~min}$ showed the same results presented for $10 \mathrm{~min}$, i.e., PAW and distilled water with $\mathrm{pH} 3.5$ significantly reduced the viability of $S$. aureus when compared to the control ( $p=0.0014$ and 0.0016 , respectively). Therefore, our results showed a reduction of 3-log UFC-mL ${ }^{-1}$, which is similar to the result obtained previously by Zhang et al. [57]. However, these authors used deionized water exposed to argon and oxygen $\left(2 \% \mathrm{Ar} / \mathrm{O}_{2}\right)$ and a dielectric barrier discharge plasma reactor (DBD) for $5 \mathrm{~min}$. Also, the time of water exposure to plasma was longer than that used in our study (40 min). Pemen et al. [58] reported that PAW produced from tap water using a transient arc plasma reactor and a loop system could inhibit Staphylococcus epidermidis after $20 \mathrm{~min}$ of exposure. In the present work, PAW and distilled water with $\mathrm{pH} 3.5$ showed a similar inhibition effect $(p>0.05)$ in S. aureus.

On the other hand, the PAW significantly reduced the number of $E$. coli after $10 \mathrm{~min}$ of exposure, both to non-activated tap water $(p=0.0002)$ and distilled water $\mathrm{pH} 3.5(p=0.0498)$ (Figure 8). Interestingly, after $30 \mathrm{~min}$ of exposure, no differences were detected between the groups to the control $(p>0.05)$. A previous study reported the effect of PAW on E. coli contained in a mixed suspension with Klebsiella pneumoniae, Acinetobacter baumannii, and Pseudomonas aeruginosa, where PAW was obtained after exposure of distilled water to the gliding arc discharge for $10 \mathrm{~min}$, and E. coli was inhibited after $20 \mathrm{~min}$ of contact [59]. In addition, Traylor et al. [42] observed a significant reduction in E. coli after $15 \mathrm{~min}$ of exposure to PAW produced by the air dielectric barrier discharge. 


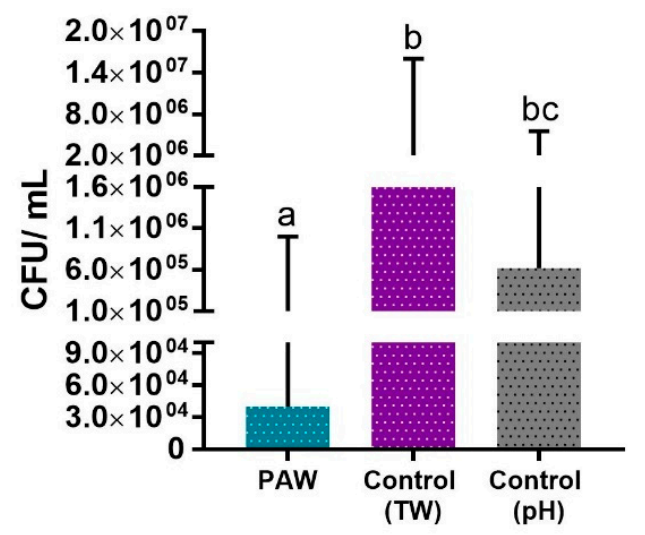

Time $10 \mathrm{~min}$

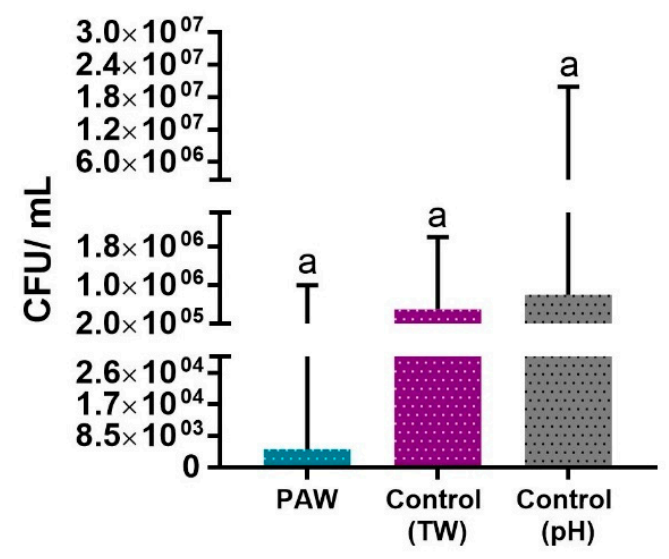

Time $30 \mathrm{~min}$

(a)

(b)

Figure 8. Median and range values of the number of Escherichia coli viable cells (CFU/mL) after exposure to plasma activated water (PAW) for 10 and $30 \mathrm{~min}$. TW: non-activated tap water (negative control); Control (pH): distilled water $\mathrm{pH}$ 3.5. Different superscript letters indicate significant differences among the groups. $(p<0.05)$ based on ANOVA statistical test followed by Kruskal-Wallis and Dunn's post hoc test.

No significant reduction in the $C$. albicans count was detected after contact with PAW or distilled water with $\mathrm{pH} 3.5$ ( $p>0.05$ ) exposed for 10 or $30 \mathrm{~min}$ periods (Figure 9). These results differ from a previous study in which PAW, generated by the exposure of deionized water exposed to air plasma prepared in a DBD reactor for $5 \mathrm{~min}$, showed an inhibitory effect on the suspension of $C$. albicans [60]. The impact of PAW on fungi species has been little investigated so far, and future studies using different parameters should be performed. The differences in the susceptibility of $C$. albicans to PAW, when compared to bacterial species, can be correlated to other cellular components, notably the fungal cell wall that presents several peculiarities [61].

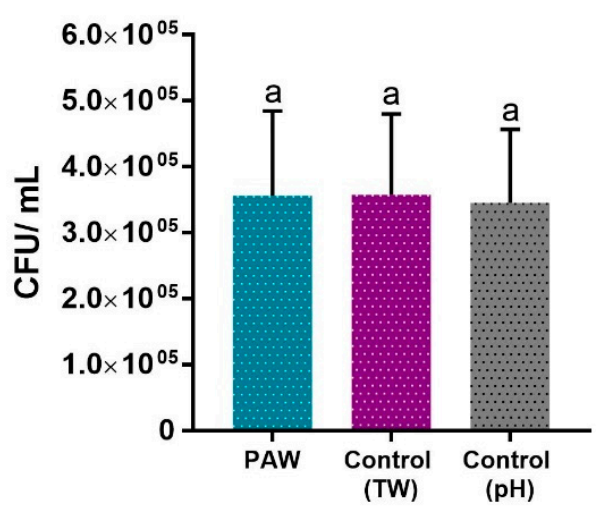

Time $10 \mathrm{~min}$

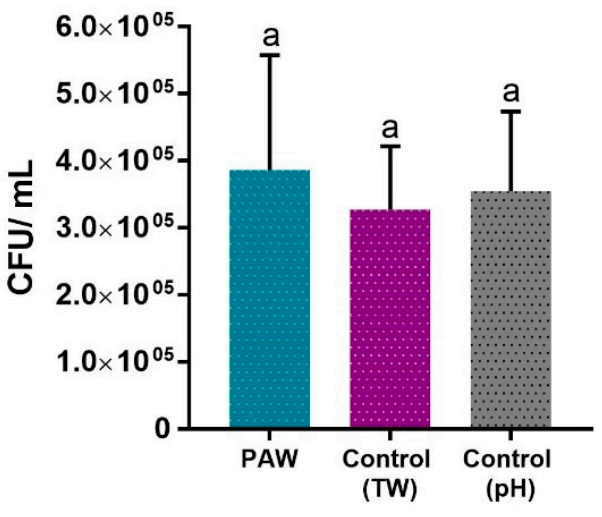

Time $30 \mathrm{~min}$

(a)

(b)

Figure 9. Mean and standard deviation of the number of viable cells of Candida albicans after exposure to plasma activated water (PAW) for 10 and $30 \mathrm{~min}$. TW: non-activated tap water (negative control); Different superscript letters indicate significant differences among the groups. $(p<0.05)$ based on ANOVA statistical test followed by Tukey's post hoc test.

The antimicrobial effect of PAW has been correlated with reactive oxygen and nitrogen species [62]. Oxidizing species are formed in aqueous solutions and can vary considerably depending on the gas mixture used for plasma formation [63], but the presence of nitrites, nitrates, and $\mathrm{H}_{2} \mathrm{O}_{2}$ is highlighted [64]. The role of peroxynitrite on the antimicrobial 
activity of PAW has been also suggested $[30,60]$ as it can damage biologic molecules, such as membranes and DNA [65]. In the present study, reactive species' presence was proven by a set of parameters such as $\mathrm{pH}$, the potential of oxidizing and reduction, and electrical conductivity [66].

Another factor often related to the antimicrobial effect is acidification. Previous studies have suggested that water acidification and the presence of reactive species (such as $\mathrm{OH}$, $\mathrm{NO}_{2-}, \mathrm{OH}^{-}$) act synergistically in PAW [60,62]. To investigate the extent of pH effect on antimicrobial activity, microbial suspensions were exposed to distilled water adjusted to pH 3.5 with $\mathrm{HCl}$. However, it is essential to note that PAW inhibition and distilled water with $\mathrm{pH} 3.5$ should be compared with caution since $\mathrm{HCl}$ is a strong oxidizer.

Interestingly, the bacterial species included in this study behaved differently in these trials. For S. aureus, PAW and distilled water at pH 3.5 showed similar inhibitory effects after 10 and 30 min of exposure, suggesting that acidification has an essential role in the inhibitory process. On the other hand, for E. coli, PAW was significantly more effective than distilled water at $\mathrm{pH} 3.5$ after 10 min of exposure, suggesting that reactive species played a central role. It can also be inferred that short-lived reactive species mediate the inhibition of E. coli in PAW since no inhibitory effect was observed after 30 min of contact. Nitric oxide, hydroxyl radicals, superoxide, peroxynitrite, and peroxynitrite are the short-lived reactive species most frequently encountered [63].

\section{Conclusions}

This experimental study explored and discussed the antimicrobial effect of plasma activated tap water (PAW) prepared using an atmospheric pressure gliding arc plasma jet generated in a forward vortex flow reactor (FVFR) type. Its potential antimicrobial activity was investigated against the following microorganisms: Staphylococcus aureus, Escherichia coli and Candida albicans. For this, we carried out a comprehensive characterization of the physicochemical characteristics of PAW in two treatment conditions: stagnant water and agitated water at $200 \mathrm{rpm}$. The PAW obtained under agitation conditions showed a more uniform acidity between the areas evaluated with pH 3.5 and ORP of $215 \mathrm{mV}$. These parameters are related to the long-lived RONS species, namely, ozone $\left(\mathrm{O}_{3}\right)$, hydrogen peroxide $\left(\mathrm{H}_{2} \mathrm{O}_{2}\right)$, nitrates $\left(\mathrm{NO}_{3}{ }^{-}\right)$and nitrites $\left(\mathrm{NO}_{2}{ }^{-}\right)$[8,52-55]. Thus, the FVFR $\mathrm{G}$ arc system with moving water proved to be a very efficient activation treatment for tap water compared to the DBD system [46] and Inductively Limited Discharge [24]. Finally, S. aureus, E. coli and C. albicans were put in contact with PAW to assess antimicrobial activity through statistical analysis.

According to our results, PAW has an excellent antimicrobial potential to inactivate $S$. aureus and E. coli due to the low pH 3.5 and high oxidation-reduction potential (ORP) of $220 \mathrm{mV}$ achieved by the FVFR G arc. This antibacterial effect is related to the interaction between reactive species (RONS) present in PAW and microbial species. The presence of RONS in PAW was confirmed by a set of parameters such as $\mathrm{pH}$, ORP and electrical conductivity [66]. Probably, the interaction between long-lived $\mathrm{RONS}\left(\mathrm{H}_{2} \mathrm{O}_{2}, \mathrm{NO}_{3}{ }^{-}\right.$and $\mathrm{NO}_{2}{ }^{-}$) and bacterial species was responsible for damaging biological molecules, such as membranes and DNA [65]. For S. aureus, the results suggest that there is a dependence between acidification and the inhibitory process due to similar inhibitory effects after 10 and 30 min of exposure to PAW and distilled water at pH 3.5. For E. coli, PAW was significantly more effective, showing that reactive species played a central role. However, no significant antimicrobial activity has been achieved for $C$. albicans. Further studies are necessary to improve antifungal activity of PAW produced by gliding arc plasma jet.

Author Contributions: Conceptualization, W.C., F.M., C.K.-I., A.d.G.S. and R.P.; methodology, W.C., A.d.G.S., F.M. and R.P.; software, W.C., A.d.G.S., F.M. and R.P.; formal analysis, A.d.G.S., C.K.I. and W.C.; investigation, A.d.G.S., W.C., M.F. and R.P.; resources, M.F., A.d.S.S., G.P. and R.P.; writing-original draft preparation, W.C., A.d.G.S., C.K.-I. and R.P.; writing-review and editing, W.C., A.d.G.S., F.M., M.F., A.d.S.S., G.P., K.K., C.K.-I. and R.P.; supervision, R.P. and C.K.-I.; project 
administration, R.P.; funding acquisition, W.C., M.F., A.d.S.S., G.P. and R.P. All authors have read and agreed to the published version of the manuscript.

Funding: This research was funded by Brazilian agency program FAPESP grant $\mathrm{n}^{\circ}$. (18/01265-1, and 19/05856-7, and 19/25652-7), CNPq (grant $n^{\circ} .446545 / 2014-7,308127 / 2018-8$ and 437921/2018-2) and the Brazilian Space Agency (AEB/Uniespaço) is also gratefully acknowledged. W. Chiappim thanks the individual grant financed by FAPESP grant $n^{\circ}$. 20/10450-7.

Institutional Review Board Statement: Not Applicable.

Informed Consent Statement: Not Applicable.

Data Availability Statement: The data that support the findings of this study are available from the corresponding author upon reasonable request.

Conflicts of Interest: The authors declare no conflict of interest.

\section{References}

1. Subramanian, P.S.G.; Jain, A.; Shivapuji, A.M.; Sundaresan, N.R.; Dasappa, S.; Rao, L. Plasma-activated water from a dielectric barrier discharge plasma source for the selective treatment of cancer cells. Plasma Process. Polym. 2020, 17, 201900260. [CrossRef]

2. Li, Y.; Pan, J.; Ye, G.; Zhang, Q.; Wang, J.; Zhang, J.; Fang, J. In vitro studies of the antimicrobial effect of non-thermal plasmaactivated water as a novel mouthwash. Eur. J. Oral Sci. 2017, 125, 463. [CrossRef] [PubMed]

3. Xu, D.; Wang, S.; Li, B.; Qi, M.; Feng, R.; Li, Q.; Zhang, H.; Chen, H.; Kong, M.G. Effects of plasma-activated water on skin wound healing in mice. Microorganisms 2020, 8, 1091. [CrossRef] [PubMed]

4. Bruggeman, P.; Leys, C. Non-thermal plasmas in and in contact with liquids. J. Phys. D Appl. Phys. 2009, 42, 053001. [CrossRef]

5. Jablonowski, H.; von Woedtke, T. Research on plasma medicine-relevant plasma-liquid interaction: What happened in the past five years? Clin. Plasma Med. 2015, 3, 42-52. [CrossRef]

6. Ramli, N.A.H.; Zaaba, S.K.; Mustaffa, M.T.; Zakaria, A.; Ab, S. Review on the development of plasma discharge in liquid solution. AIP Conf. Proc. 2017, 1824, 030015.

7. Gamaleev, V.; Iwata, N.; Hori, M.; Hiramatsu, M.; Ito, M. Direct treatment of liquids using low-current arc in ambient air for biomedical applications. Appl. Sci. 2019, 9, 3505. [CrossRef]

8. Zhou, R.; Zhou, R.; Wang, P.; Xian, Y.; Mai-Prochnow, A.; Lu, X.; Cullen, P.J.; Ostrikov, K.; Bazaka, K. Plasma-activated water: Generation, origin of reactive species and biological applications. J. Phys. D Appl. Phys. 2020, 53, 303001. [CrossRef]

9. Yoon, S.-Y.; Jeon, H.; Yi, C.; Park, S.; Ryu, S.; Kim, S.B. Mutual interaction between plasma characteristics and liquid properties in AC-driven pin-to-liquid discharge. Sci. Rep. 2018, 8, 12037. [CrossRef]

10. Zhang, J.J.; Kwon, T.; Kim, S.B.; Jeong, D.K. Plasma farming: Non-thermal dielectric barrier discharge plasma technology for improving the growth of soybean sprouts and chickens. Plasma 2018, 1, 285-296. [CrossRef]

11. Ito, M.; Oh, J.-S.; Ohta, T.; Shiratani, M.; Hori, M. Current status and future prospects of agricultural applications using atmospheric-pressure plasma technologies. Plasma Proc. Polym. 2017, 15, e1700073. [CrossRef]

12. Judée, F.; Simon, S.; Bailly, C.; Dufour, T. Plasma-activation of tap water using DBD for agronomy applications: Identification and quantification of long lifetime chemical species and production/consumption mechanisms. Water Res. 2018, 133, 47. [CrossRef] [PubMed]

13. Zhang, X.; Zhou, R.; Bazaka, K.; Liu, Y.; Zhou, R.; Chen, G.; Chen, Z.; Liu, Q.; Yang, S.; Ostrikov, K. Quantification of plasma produced $\mathrm{OH}$ radical density for water sterilization. Plasma Proc. Polym. 2018, 15, e1700241. [CrossRef]

14. Zhang, Z.; Shen, J.; Cheng, C.; Xu, Z.; Xia, W. Generation of reactive species in atmospheric pressure dielectric barrier discharge with liquid water. Plasma Sci. Tech. 2018, 20, 044009. [CrossRef]

15. Nascimento, L.; Gasi, F.; Landers, R.; da Silva Sobrinho, A.; Aragão, E.; Fraga, M.; Petraconi, G.; Chiappim, W.; Pessoa, R. Physicochemical studies on the surface of polyamide 6.6 fabrics functionalized by DBD plasmas operated at atmospheric and sub-atmospheric pressures. Polymers 2020, 12, 2128. [CrossRef] [PubMed]

16. Miranda, F.S.; Rabelo, S.C.; Pradella, J.G.C.; Di Carli, C.; Petraconi, G.; Maciel, H.S.; Pessoa, R.S.; Vieira, L. Plasma in-liquid using non-contact electrodes: A method of pretreatment to enhance the enzymatic hydrolysis of biomass. Waste Biomass. Valor. 2020, 11, 4921-4931. [CrossRef]

17. Figueira, F.R.; Doria, A.C.O.C.; Khouri, S.; Maciel, H.S.; Pessoa, R.S.; Ramos, M.A.R. Effect of storage temperature on pH and conductivity of reverse osmosis water treated with atmospheric plasma. Plasma Med. 2018, 8, 237-244. [CrossRef]

18. Kolb, J.F.; Joshi, R.P.; Xiao, S.; Schoenbach, K.H. Streamers in water and other dielectric liquids. J. Phys. D Appl. Phys. 2008, 41, 234007. [CrossRef]

19. Bruggeman, P.; Ribezl, E.; Maslani, A.; Degroote, J.; Malesevic, A.; Rego, R.; Vierendeels, J.; Leys, C. Characteristics of atmospheric pressure air discharges with a liquid cathode and a metal anode. Plasma Sources Sci. Technol. 2008, 17, 025012. [CrossRef]

20. Chen, C.W.; Lee, H.-M.; Chang, M.B. Inactivation of aquatic microorganisms by low-frequency AC discharges. IEEE Trans. Plasma Sci. 2008, 36, 215. [CrossRef] 
21. Kovacevic, V.V.; Dojcinovic, B.P.; Jovic, M.; Roglic, G.M.; Obradovic, B.M.; Kuraica, M.M. Measurement of reactive species generated by dielectric barrier discharge in direct contact with water in different atmospheres. J. Phys. D Appl. Phys. 2017, 50, 155205. [CrossRef]

22. Oehmigen, K.; Hähnel, M.; Brandenburg, R.; Wilke, C.; Weltmann, K.-D.; von Woedtke, T. The role of acidification for antimicrobial activity of atmospheric pressure plasma in liquids. Plasma Process. Polym. 2010, 7, 250. [CrossRef]

23. Burlica, R.; Kirkpatrick, M.J.; Locke, B.R. Formation of reactive species in gliding arc discharges with liquid water. J. Electrostat. 2006, 64, 35. [CrossRef]

24. Schmidt, M.; Hahn, V.; Altrock, B.; Gerling, T.; Gerber, I.C.; Weltmann, K.-D.; von Woedtke, T. Plasma-activation of larger liquid volumes by an inductively-limited discharge for antimicrobial purposes. Appl. Sci. 2019, 9, 2150. [CrossRef]

25. Han, S.H.; Suh, H.J.; Hong, K.B.; Kim, S.Y.; Min, S.C. Oral Toxicity of Cold Plasma-Treated Edible Films for Food Coating. J. Food Sci. 2016, 81, T3052-T3057. [CrossRef]

26. Borges, A.C.; Lima, G.M.G.; Nishime, T.M.C.; Gontijo, A.V.L.; Kostov, K.G.; Koga-Ito, C.Y. Amplitude-modulated cold atmospheric pressure plasma jet for treatment of oral candidiasis: In vivo study. PLoS ONE 2018, 13, e0199832. [CrossRef]

27. İbiş, F.; Ercan, U.K. Inactivation of biofilms in endotracheal tube by cold atmospheric plasma treatment for control and prevention of ventilator-associated pneumonia. Plasma Proc. Polym. 2020, 17, 2000065. [CrossRef]

28. Tang, Q.; Jiang, W.; Cheng, Y.; Lin, S.; Lim, T.M.; Xiong, J. Generation of reactive species by gas-phase dielectric barrier discharges. Ind. Eng. Chem. Res. 2011, 50, 9839. [CrossRef]

29. Xu, H.; Liu, D.; Wang, W.; Liu, Z.; Guo, L.; Rong, M.; Kong, M.G. Investigation on the RONS and bactericidal effects induced by $\mathrm{He}+\mathrm{O}_{2}$ cold plasma jets: In open air and in an airtight chamber. Phys. Plasmas 2018, 25, 113506. [CrossRef]

30. Zhou, R.; Zhou, R.; Prasad, K.; Fang, Z.; Speight, R.; Bazaka, K.; Ostrikov, K. Cold atmospheric plasma activated water as a prospective disinfectant: The crucial role of peroxynitrite. Green Chem. 2018, 20, 5276. [CrossRef]

31. Oh, J.-S.; Kakuta, M.; Furuta, H.; Akatsuka, H.; Hatta, A. Effect of plasma jet diameter on the efficiency of reactive oxygen and nitrogen species generation in water. Jpn. J. Appl. Phys. 2016, 55, 06HD01. [CrossRef]

32. Chauvin, J.; Judée, F.; Yousfi, M.; Vicendo, P.; Merbahi, N. Analysis of reactive oxygen and nitrogen species generated in three liquid media by low temperature helium plasma jet. Sci. Rep. 2017, 7, 4562. [CrossRef] [PubMed]

33. Ogawa, K.; Oh, J.-S.; Gaur, N.; Hong, S.-H.; Kurita, H.; Mizuno, A.; Hatta, A.; Short, R.D.; Ito, M.; Szili, E.J. Modulating the concentrations of reactive oxygen and nitrogen species and oxygen in water with helium and argon gas and plasma jets. Jpn. J. Appl. Phys. 2019, 58, SAAB01. [CrossRef]

34. Iwata, N.; Gamaleev, V.; Hashizume, H.; Oh, J.-S.; Ohta, T.; Ishikawa, K.; Hori, M.; Ito, M. Simultaneous achievement of antimicrobial property and plant growth promotion using plasma-activated benzoic compound solution. Plasma Proc. Polym. 2019, 16, e1900023. [CrossRef]

35. Kim, D.Y.; Kim, S.J.; Joh, H.M.; Chung, T.H. Characterization of an atmospheric pressure plasma jet array and its application to cancer cell treatment using plasma activated medium. Phys. Plasma 2018, 25, 073505. [CrossRef]

36. Zhou, R.; Zhou, R.; Zhuang, J.; Zong, Z.; Zhang, X.; Liu, D.; Bazaka, K.; Ostrikov, K. Interaction of atmospheric-pressure air microplasmas with amino acids as fundamental processes in aqueous solution. PLoS ONE 2016, 11, e0155584. [CrossRef]

37. Gharagozalian, M.; Dorranian, D.; Ghoranneviss, M. Water treatment by the AC gliding arc air plasma. J. Theor. Appl. Phys. 2017, 11, 171. [CrossRef]

38. Guofeng, X.; Xinwei, D. Electrical characterization of a reverse vortex gliding arc reactor in atmosphere. IEEE Trans. Plasma Sci. 2012, 40, 3458. [CrossRef]

39. Doria, A.C.O.C.; Figueira, F.R.; de Lima, J.S.B.; Figueira, J.A.N.; Castro, A.H.R.; Sismanoglu, B.N.; Petraconi, G.; Maciel, H.S.; Khouri, S.; Pessoa, R.S. Inactivation of Candida albicans biofilms by atmospheric gliding arc plasma jet: Effect of gas chemistry/flow and plasma pulsing. Plasma Res. Express 2019, 1, 015001. [CrossRef]

40. Hänsch, M.A.C.; Mann, M.; Weltmann, K.-D.; von Woedtke, T. Analysis of antibacterial efficacy of plasma-treated sodium chloride solutions. J. Phys. D Appl. Phys. 2015, 48, 454001. [CrossRef]

41. Oehmigen, K.; Winter, J.; Hähnel, M.; Wilke, C.; Brandenburg, R.; Weltmann, K.-D.; von Woedtke, T. Estimation of possible mechanisms of Escherichia coli inactivation by plasma treated sodium chloride solution. Plasma Process. Polym. 2011, 8, 904. [CrossRef]

42. Traylor, M.J.; Pavlovich, M.J.; Karim, S.; Hait, P.; Sakiyama, Y.; Clark, D.S.; Graves, D.B. Long-term antibacterial efficacy of air plasma-activated water. J. Phys. D Appl. Phys. 2011, 44, 472001. [CrossRef]

43. Joslin, J.M.; McCall, J.R.; Bzdek, J.P.; Johnson, D.C.; Hybertson, B.M. Aqueous plasma pharmacy: Preparation methods, chemistry, and therapeutic applications. Plasma Med. 2016, 6, 135. [CrossRef] [PubMed]

44. Inmetro. Available online: http:/ / www.inmetro.gov.br/laboratorios/rble/docs/CRL0168.pdf (accessed on 28 January 2021).

45. Miles, A.A.; Misra, S.S.; Irwin, J.O. The estimation of the bactericidal power of the blood. Blood J. Hyg. 1938, 38, 732-749. [CrossRef]

46. Xiang, Q.; Liu, X.; Liu, S.; Ma, Y.; Xu, C.; Bai, Y. Effect of plasma-activated water on microbial quality and physicochemical characteristics of mung bean sprouts. Innov. Food Sci. Emer. Technol. 2019, 58, 49-56. [CrossRef]

47. Xiang, Q.; Zhang, R.; Fan, L.; Ma, Y.; Wu, D.; Li, K.; Bai, Y. Microbial inactivation and quality of grapes treated by plasma-activated water combined with mild heat. LWT 2020, 126, 109336. [CrossRef] 
48. Zhao, Y.-M.; Ojha, S.; Burgess, C.M.; Sun, D.-W.; Tiwari, B.K. Inactivation efficacy and mechanisms of plasma activated water on bacteria in planktonic state. J. Appl. Microbiol. 2020, 129, 14677. [CrossRef]

49. Chen, D.; Chen, P.; Cheng, Y.; Peng, P.; Liu, J.; Ma, Y.; Liu, Y.; Ruan, R. Deoxynivalenol decontamination in raw and germinating barley treated by plasma-activated water and intense pulsed light. Food Bioproc. Tech. 2019, 12, 246-254. [CrossRef]

50. Lu, P.; Boehm, D.; Bourke, P.; Cullen, P.J. Achieving reactive species specificity within plasma-activated water through selective generation using air spark and glow discharges. Plasma Process. Polym. 2017, 14, e1600207. [CrossRef]

51. Patange, A.; Lu, P.; Boehm, D.; Cullen, P.J.; Bourke, P. Efficacy of cold plasma functionalised water for improving microbiological safety of fresh produce and wash water recycling. Food Microbiol. 2019, 84, 103226. [CrossRef]

52. Liao, L.B.; Chen, W.M.; Xiao, X.M. The generation and inactivation mechanism of oxidation-reduction potential of electrolyzed oxidizing water. J. Food Eng. 2007, 78, 1326-1332. [CrossRef]

53. Lukes, P.; Clupek, M.; Babicky, V.; Sunka, P. Ultraviolet radiation from the pulsed corona discharge in water. Plasma Sources Sci. Technol. 2008, 17, 024012. [CrossRef]

54. Suslow, T. Oxidation-Reduction Potential (ORP) for Water Disinfection Monitoring. Control and Documentation, University of California, Division of Agriculture and Natural Resources. Available online: https://doi.org/10.3733/ucanr.8149 (accessed on 10 April 2021).

55. Strom, M.; Crowley, T.; Shigdar, S. Novel detection of nasty bugs, prevention is better than cure. Int. J. Mol. Sci. 2021, 22, 149. [CrossRef] [PubMed]

56. Spampinato, C.; Leonardi, D. Candida infections, causes, targets, and resistance mechanisms: Traditional and alternative antifungal agents. Biomed. Res. Int. 2013, 2013, 204237. [CrossRef] [PubMed]

57. Zhang, Z.; Xu, Z.; Cheng, C.; Wei, J.; Lan, Y.; Ni, G.; Sun, Q.; Qian, S.; Zhang, H.; Xia, W.; et al. Bactericidal effects of plasma induced reactive species in dielectric barrier gas-liquid discharge. Plasma Chem. Plasma Process. 2017, 37, 415-431. [CrossRef]

58. Pemen, A.J.M.; van Ooij, P.P.; Beckers, F.J.C.M.; Hoeben, W.F.L.M.; Koonen-Reemst, A.M.C.B.; Huiskamp, T.; Leenders, P.H.M. Power modulator for high-yield production of plasma-activated water. IEEE Trans. Plasma Sci. 2017, 45, 2725-2733. [CrossRef]

59. Balan, G.G.; Roşca, I.; Ursu, E.-L.; Doroftei, F.; Bostănaru, A.-C.; Hnatiuc, E.; Năstasă, V.; Şandru, V.; Ştefănescu, G.; Mareş, M. Plasma-activated water: A new and effective alternative for duodenoscope reprocessing. Infect. Drug Resit. 2018, 11, 727-733. [CrossRef]

60. Laurita, R.; Barbieri, D.; Gherardi, M.; Colombo, V.; Lukes, P. Chemical analysis of reactive species and antimicrobial activity of water treated by nanosecond pulsed DBD air plasma. Clin. Plasma Med. 2015, 3, 53-61. [CrossRef]

61. Garcia-Rubio, R.; de Oliveira, H.C.; Rivera, J.; Trevijano-Contador, N. The fungal cell wall: Candida, Cryptococcus, and Aspergillus species. Front. Microbiol. 2020, 10, 2993. [CrossRef]

62. Hoeben, W.F.L.M.; van Ooij, P.P.; Schram, D.C.; Huiskamp, T.; Pemen, A.J.M.; Lukeš, P. On the possibilities of straightforward characterization of plasma activated water. Plasma Chem. Plasma Process. 2019, 39, 597-626. [CrossRef]

63. Hefny, M.M.; Pattyn, C.; Lukes, P.; Benedikt, J. Atmospheric plasma generates oxygen atoms as oxidizing species in aqueous solutions. J. Phys. D Appl. Phys. 2016, 49, 404002. [CrossRef]

64. Naïtali, M.; Kamgang-Youbi, G.; Herry, J.-M.; Bellon-Fontaine, M.-N.; Brisset, J.-L. Combined effects of long-living chemical species during microbial inactivation using atmospheric plasma-treated water. Appl. Environ. Microbiol. 2010, 76, 7662-7664. [CrossRef] [PubMed]

65. Zhu, L.; Guun, C.; Beckman, J.S. Bactericidal activity of peroxynitrite. Arch. Biochem. Biophys. 1992, 298, 452-457. [CrossRef]

66. Thirumdas, R.; Kothakota, A.; Annapure, U.; Siliveru, K.; Blundell, R.; Gatt, R.; Valdramidis, V.P. Plasma activated water (PAW): Chemistry, physico-chemical properties, applications in food and agriculture. Trends Food Sci. Technol. 2018, 77, 21-31. [CrossRef] 